\title{
EVALUATION OF ANTIOXIDANT ACTIVITY OF AMARANTHUS VIRIDIS L. METHANOLIC EXTRACT
}

\author{
Vrushali Jadhav and S.D. Biradar \\ Department of Botany, Dnyanopasak Shikshan Mandal's, College of Arts, Commerce \\ and Science, Parbhani - 431401 (M.S.) India.
}

\begin{abstract}
*Corresponding Author Email: jadhav_vrushali@yahoo.com
ABSTRACT

Plants and plants products have been claimed to have health-promoting effects, which may be related to the antioxidant activity in vitro. The aim of this study was to determine antioxidant activity of selected plant Amaranthus viridis Linn, the antioxidant activities of different concentrations of methanol extracts of leaves of Amaranthus viridis was determined by DPPH radical scavenging assay. Methanol extract of leaves of Amaranthus viridis has shown effective antioxidant activity in DPPH assay technique. The results obtained in the present study indicate that the leaves of Amaranthus viridis is a potential source of natural antioxidants.
\end{abstract}

\section{KEY WORDS}

Antioxidant activity, DPPH, reducing power, Amaranthus viridis Linn.

\section{INTRODCTION}

Numerous physiological and biochemical processes in the human body may produce oxygen-centered free radicals and other reactive oxygen species as by products. Over production of such free radicals can cause oxidative damage to biomolecules (e.g. lipids,proteins, DNA), eventually leading to many chronic diseases, such as atherosclerosis, cancer,diabetes, aging, and other degenerative diseases in humans $(1,2,3)$. Plants (fruits, vegetables, medicinal herbs, etc.) and products made from plants may contain a wide variety of free radical scavenging molecules, such as phenolic compounds (e.g. phenolic acids, flavonoids, quinones, coumarins, lignans, stilbenes, tannins), nitrogen compounds (alkaloids, amines, betalains), vitamins, terpenoids (including carotenoids), and some other endogenous metabolites, which are rich in antioxidant activity $(4,5,6,7,8)$ Antioxidants are very important also in many foods to prevent fat rancidity (9). Synthetic antioxidants such as butylated hydroxyanisole (BHA) and butylated hydroxytoluene (BHT) are widely used because they are effective and cheaper than natural ones (10). However, the safety and toxicity of synthetic antioxidants have raised important concerns. Hence, considerable interest has been given to the use of natural antioxidants which may also have nutritional properties (9). Amaranthus viridis Linn, belongs to family Amaranthaceae and is traditionally used for treatment of constipation, inflammation, eczema, bronchitis, anaemia, and leprosy $(11,12,13)$. Flavonoids are a group of polyphenolic compounds, which are widely distributed throughout the plant kingdom. To date about 300 varieties of flavonoids are known (14). Many have low toxicity in mammals and some of them are widely used in medicine for maintenance of capillary integrity. The main objective of the present work was to evaluate of antioxidant potential of methanolic extract of leaves of Amaranthus viridis $L$.

\section{MATERIALS AND METHODS}

a) Extraction of plant material

$10 \mathrm{~g}$ leaf powder of $\mathrm{A}$. viridis were extracted with methanol using a Soxhlet apparatus for six to eight hours. Then extracts were filtered, evaporated and 
weights were taken. The dried extracts were dissolved in dimethyl sulphoxide (DMSO).

\section{b) Preparation of Standard}

Vit. C (Ascorbic acid) was used as a comparative standard.

\section{c) DPPH Photometric Assay}

The antioxidant activity of plant extract was determined using the 1, 1-diphenyl-2 picrylhydrazyl (DPPH) free radical scavenging assay. The free radical scavenging capacity of methanolic extract of plant material was determined using DPPH. The stock solution $(10 \mathrm{mg} / 100 \mathrm{ml})$ was prepared using DPPH solution $(0.004 \% \mathrm{w} / \mathrm{v})$ in $95 \%$ methanol. From the stock solution $2 \mathrm{ml}, 4 \mathrm{ml}, 6 \mathrm{ml}, 8 \mathrm{ml}$ and $10 \mathrm{ml}$ of this solution were taken in five test tubes and it is diluted with methanol to make a volume up to $10 \mathrm{ml}$, which having the concentration $20 \mu \mathrm{g} / \mathrm{ml}, 40 \mu \mathrm{g} / \mathrm{ml}, 60 \mu \mathrm{g} / \mathrm{ml}$, $80 \mu \mathrm{g} / \mathrm{ml}$ and $100 \mu \mathrm{g} / \mathrm{ml}$ respectively. Freshly prepared DPPH solution $(0.04 \% \mathrm{w} / \mathrm{v})$ was added in each of these test tubes containing plant extract $(20 \mu \mathrm{g} / \mathrm{ml}, 40 \mu \mathrm{g} / \mathrm{ml}$, $60 \mu \mathrm{g} / \mathrm{ml}, 80 \mu \mathrm{g} / \mathrm{ml}$ and $100 \mu \mathrm{g} / \mathrm{ml}$ ) and after 10 minutes the absorbance was taken at $517 \mathrm{~nm}$ using spectrophotometer. Ascorbic acid was used as a reference standard which is prepared by dissolving it in distilled water. The stock solution was prepared with the same concentration $(10 \mathrm{mg} / 100 \mathrm{ml}$ or $100 \mu \mathrm{g} / \mathrm{ml})$ of plant extract. Control sample was prepared using the same volume without any extract and reference ascorbic acid. The $95 \%$ methanol was used as blank.
The Percent scavenging of the DPPH free radical was measured using the following equation:

$\% \mathrm{DPPH}$ radical scavenging $=($ Absorbance of ControlAbsorbance of test sample)/ (Absorbance of control) $\times$ 100 (15).

\section{d) Estimation of total phenolic content}

The assay used for the determination of total phenolics content employs Folin and Ciocalteu's phenol reagent which response depending on the chemical structure of phenolics (i.e. the higher the number of functional $\mathrm{OH}$ group the higher the total phenolics content). Total soluble phenolic compounds in the ethanolic extracts were measured and expressed as gallic acid equivalents. A sample of the ethanolic extract was added to distilled water for a final volume of $2 \mathrm{ml}$. After, it was mixed with $0.3 \mathrm{ml}$ of a saturated sodium carbonate $\left(\mathrm{Na}_{2} \mathrm{CO}_{3}\right)$ solution and $0.1 \mathrm{ml}$ of $1 \mathrm{~N}$ FolinCiocalteu's phenol reagent. The mixture was placed for $1 \mathrm{~h}$ room temperature in the dark. The absorbance was measured at $725 \mathrm{~nm}$ against the blank. The total phenolic content was expressed as $\mathrm{mg}$ of gallic acid equivalent.

\section{RESULTS}

\section{Antioxidant activity of $A$. viridis}

The highest IC 50 value (61.72) was observed at $80 \mu \mathrm{g} / \mathrm{ml}$ concentration while 31.85, 47.97, 34.22, 34.99 values of $\mathrm{IC}_{50}$ had concentration range of 20,40 , $60,100 \mu \mathrm{g} / \mathrm{ml}$ (Table No.1).

\begin{tabular}{lll}
\hline \multirow{2}{*}{ Concentration $\mu \mathrm{g} / \mathrm{ml}$ I } & IC so Values & Standard \\
\cline { 2 - 3 } & A.viridis methanolic extract & Ascorbic acid \\
\hline 20 & $31.85 \pm 0.06$ & $99.80 \pm 1.34$ \\
40 & $47.97 \pm 0.33$ & $142.58 \pm 1.69$ \\
60 & $\mathbf{6 1 . 7 2 \pm 0 . 1 2}$ & $89.76 \pm 1.05$ \\
80 & $34.22 \pm 0.53$ & $49.18 \pm 0.03$ \\
100 & $33.49 \pm 0.07$ & $113.56 \pm 1.44$ \\
\hline
\end{tabular}

Table 1: Antioxidant activity of A.viridis (Mean \pm S.D).

\section{Total Polyphenol content}

Since polyphenols significantly contribute to the overall antioxidant activity, which is expressed in $\mathrm{mg} / 100 \mathrm{~g}$ during present study A.viridis contains $161.91 \mathrm{mg} / 100 \mathrm{~g}$ polyphenols.

\section{DISCUSSION}

The antioxidants protect from the potentially damaging oxidative stress, which is a result of an imbalance between the formation of ROS and the body antioxidant defense. Antioxidants have also been used in food industry to prevent deterioration, nutritional losses and off-flavoring in various foods, especially those containing polyunsaturated fatty 
acids. Recently, interest has increased considerably in finding naturally occurring antioxidants for use in foods because of their potential in health promotion and disease prevention, and their high safety and consumer acceptability Gorinstein et al., (2003). $80 \mu \mathrm{g} / \mathrm{ml}$ concentration of A.viridis shows highest IC 50 values(61.72) while 34.83, 46.85, 47.97, 98.30 values of $\mathrm{IC}_{50}$ has concentration range of 20,40, $60,100 \mu \mathrm{g} / \mathrm{ml}$. DPPH radical scavenging assay of the methanolic extracts of the plant show a dose response pattern, which was comparably lower than that of the ascorbic acid .However, it was observed that the percentage DPPH scavenging activity of the methanolic extract was higher in A.viridis by comparing it to the activity of known antioxidants such as Ascorbic acid (Vit.C). Singh (2002) were studied that the antioxidant property of $A$. spinosus growing along roadside which is continuously exposed to the high levels of nitrogen oxides and sulphur dioxide through automobile emission which is correlated with present study. Polyphenols are widely common secondary metabolites of plants, the content of which varies greatly between different species, and cultivars, and with maturity, season, region and yield. Polyphenols are classified according to their structure as phenolic acids derivatives, flavonoids, stilbenes or lignans. Phenolics are compounds with one or more aromatic ring and one or more hydroxyl groups (17). Our results indicated that spices are very good sources of antioxidant phenolic compounds and can be used after isolation as food additives in lipids and lipid containing foods to minimize rancidity, retard the formation of toxic oxidation products, maintain nutritional quality and increase the shelf life of food products.

\section{CONCLUSION}

The members of amaranthaceae are usually growing in waste places or they are wild in occurance and abundant in population. In this study, we prepared and evaluated antioxidant activity of selected plant extracts. Our results showed that tested plant products had noticeably antioxidant effect and total phenolic content. Antioxidant compounds from these products with preventive and treatment effect on various diseases can be used for improving the shelf life of food products. The present study may help in use of these naturally occurring species in the development of new drugs.

\section{REFERENCES}

1. Halliwell B. Free Radicals, Antioxidants, and Human Disease: Curiosity, Cause, or Consequence in Lancet, 344: pp.721-724, (1994)

2. Niki E. Free Radicals, Antioxidants, and Cancer. In Ohigashi, H., Osawa, T., Terao, J., Watanabe, S., Yoshikawa, T. (Eds.), Food Factors for Cancer Prevention. Springer: Tokyo, 1997 pp. 55-57.

3. Poulson H. E., Prieme H. and Loft S. Role of Oxidative DNA Damage in Cancer Initiation and Promotion. In European Journal of Cancer Prevention, 7: 9-16, (1998)

4. Shahidi F and Naczk M. Food Phenolics: Sources, Chemistry, Effects and Applications. Technomic Publishing Company: Switzerland, 331: 279-3, (1995)

5. Cotelle N., Bernier J. L., Catteau J. P., Pommery J., Wallet J. C. and Gaydou E. M. Antioxidant Properties of Hydroxyflavones. In Free Radical Biology and Medicine, 20: 35-43. (1996)

6. Velioglu, Y. S. Mazza, G. Gao, L. and Oomah, B. D. Antioxidant Activity and Total Phenolics In Selected Fruits, Vegetables, and Grain Products. In Journal of Agricultural and Food Chemistry,46, 4113-4117, (1998)

7. Zheng W. and Wang S. Y. Antioxidant Activity and Phenolic Compounds in Selected herbs. Journal of Agricultural and Food Chemistry, 49: 5165-5170, (2001)

8. Cai Y. Z., Sun M. and Corke H. Antioxidant Activity of Betalains From Plants of the Amaranthaceae. Journal of Agricultural and Food Chemistry, 51: 2288-2294, (2003)

9. Jadhav S. J. Nimbalkar S. S. Kulkarni A. D. and Madhavi, D. L. Lipid oxidation in biological and food systems. In Madhavi, D.L., Deshpande, S.S., Salunkhe, D.K. (Eds.), Food Antioxidants. Marcel Dekker: New York, 1996, pp. 58-69.

10. Kirtikar K.R. and Basu B.D. Indian Materia Medica, International book distributors, Dehra Dun, India, 3,pp. 2055-57.(1987)

11. Sivarajan V.V. and Balachandran I. Ayurvedic Drugs and Their Plant Sources. Oxford and India Book House Publishing Co., Pvt. Ltd., New Delhi, pp. 473-474. (1994)

12. Anonymous. Wealth of India, publications and information directorate, CSIR, New Delhi, 1996, Vol I. Ministry of Health \& Family Welfare. Govt. of India, Controller of Publications, New Delhi, Vol II 217 pp.53 $-54,(1998)$ 
13. Kuhnau J. The flavonoids: A class of semi-essential food components: their role in human nutrition. World Res. Nut Diet, 24: 17-91, (1976)

14. Lee, S.E, Hwang, H.J. and Ha, J.S, Screening of Medicinal Plant Extracts for Antioxidant Activity, Life Science, 73:167-179, (2003)

15. Gorinstein S., Yamamoto K.., Katrich E., Leontowicz H., Lojek A., Leontowicz M., Ciz M., Goshev I., Shalev U. and Trakhtenberg S, Antioxidative properties of Jaffa sweeties and grapefruit and their influence on lipid metabolism and plasma antioxidative potential in rats, Biosci Biotechnol Biochem, 67: 907-910, (2003)

16. Singh A.B. and Dahiya P. Antigenic and allergenic properties of Amaranthus spinosus pollen - a common growing weed in India, Ann Agric Environ Med, 9:147-151, (2002)

17. LIU R. H. Health benefits of fruit and vegetables are from additive and synergistic combinations of phytochemicals. In American Journal of Clinical Nutrition, 78:517-520, (2003)

*Corresponding Author: Vrushali Jadhav*

Email:jadhav_vrushali@yahoo.com 